\title{
Analysis of putative ABC transporter genes in Mycoplasma hyopneumoniae
}

\author{
Béatrice Blanchard, ${ }^{1}$ Colette Saillard, ${ }^{2}$ Marylène Kobisch ${ }^{1}$ and \\ Joseph M. Bové2
}

Author for correspondence: Colette Saillard. Tel: +33 568431 42. Fax : +33 56843159.

1 CNEVA PLOUFRAGAN, Station de Pathologie Porcine - 22440

Ploufragan, France

2 Laboratoire de Biologie Cellulaire et Moléculaire INRA, BP 81 - 33883

Villenave d'Ornon Cedex, France

\begin{abstract}
A previously described DNA probe specific for Mycoplasma hyopneumoniae (I-141) was fully sequenced and found to consist of 1618 bp and to contain two tandemly repeated ORFs. The deduced amino acid sequence of the two ORFs showed significant homologies with ATP-binding cassette (ABC) transporter proteins, particularly those of the eukaryotic multidrug resistance (MDR) protein family (up to $21 \%$ identity and $47 \%$ similarity). A somewhat lower homology was evident with the secretion protein HlyB of the RTX-haemolysin from Escherichia coli. The location of the two ORFs on the $M$. hyopneumoniae chromosome was downstream of the rrl gene encoding the 235 rRNA, but transcribed in the opposite direction. PCR amplification and subsequent chromosomal analysis by Southern blot hybridization of several $\boldsymbol{M}$. hyopneumoniae strains showed that all field strains contained the two putative ABC transporter genes. However, some culture collection strains derived from strain J had lost these genes as the result of a 2221 bp deletion.
\end{abstract}

Keywords: mollicutes, Mycoplasma byopneumoniae, deletion, MDR proteins, ABC transporters

\section{INTRODUCTION}

Mollicutes are amongst the smallest autonomously replicating organisms, which differ structurally from other eubacteria in the lack of a cell wall, a small genome and a low $\mathrm{G}+\mathrm{C}$ content (Bové, 1993). Mycoplasma byopneumoniae colonizes the ciliated respiratory epithelium of piglets inducing loss of cilia (Blanchard et al., 1992) and is the etiological agent of enzootic pneumonia (EP) (Ross, 1992). EP is one of the most common and economically important diseases that occur in swine. Recent studies also suggest a role for $M$. byopneumoniae in the initiation of a variety of other bacterial and virus infections that occur under field conditions (Ross, 1992; Kobisch et al., 1993), but the mechanism of its pathogenicity is poorly known.

Typically, detection of $M$. byopneumoniae in pig lungs is based on culture or immunofluorescence (IF) assays (L'Ecuyer \& Boulanger, 1970; Hovind-Hougen \& Friis, 1991). However, identification by culture is laborious, and the specificity of the IF test is ambiguous, since $M$. byopneumoniae and Mycoplasma flocculare (a frequently isolated non-pathogenic pig mycoplasma) share common

Abbreviations: ABC, ATP-binding cassette; MDR, multidrug resistance. The GenBank accession numbers for the sequences reported in this paper are U02537, U02538 and U19889 (see text for details). antigenic determinants (Bölske et al., 1987). Thus, many attempts have been made to develop alternative diagnostic systems.

We have recently shown that a DNA fragment (I-141) from $M$. byopneumoniae may be used as a specific probe for the detection of $M$. byopneumoniae in tracheobronchiolar washings obtained from experimentally infected piglets (Abiven et al., 1992). Here, we report the sequence of the I-141 DNA fragment and the DNA surrounding the fragment in the M. byopneumoniae chromosome. The results show the presence of two ORFs with sequence similarities to genes encoding ABC (ATP-binding cassette) transporters. Some strains derived from strain J do not possess these genes.

\section{METHODS}

Bacterial strains, DNA and plasmids. Escherichia coli TG1 was used as the host for propagation of plasmids and viruses. $M$. byopneumoniae strain J (ATCC 25934) was received directly from ATCC and cultivated for less than ten passages in modified Friis culture medium (Hovind-Hougen \& Friis, 1991). We refer to this strain as J-LP (low passage J strain). Genomic DNA from this strain was used to constuct the I-141 probe (Abiven $e t$ al., 1992).

Purified DNA from other $M$. byopneumoniae strains, field strains and strains derived from the original strain $\mathrm{J}$ were given by 
Table 1. Source and reference of $M$. hyopneumoniae strains tested and size of DNA fragments obtained by PCR with HP1 or HP3 primers

\begin{tabular}{|c|c|c|c|}
\hline Strain & $\begin{array}{l}\text { Reference } \\
\text { or source* }\end{array}$ & Obtained from: & $\begin{array}{c}\text { Size of } \\
\text { fragment }(k b p)\end{array}$ \\
\hline J-LP & ATCC 25934 & Our laboratory & 1.6 \\
\hline BQ14 & Field isolate & Our laboratory & 1.6 \\
\hline VL4 & Field isolāte & Our laboratory & 1.6 \\
\hline $39 \mathrm{~A}$ & Field isolate & Our laboratory & $1 \cdot 6$ \\
\hline $\mathrm{J}$ & ATCC 25934 & J. Frey & $1 \cdot 8$ \\
\hline $\mathrm{J}$ & NCTC 10110 & J. Frey & $1 \cdot 8$ \\
\hline JF 184 & NCTC 10110 & J. Frey & $1 \cdot 8$ \\
\hline EP 29 & Field isolate & J. Frey & $1 \cdot 6$ \\
\hline EP-S 946 & Field isolate & J. Frey & $1 \cdot 6$ \\
\hline EP-S 924 & Field isolate & J. Frey & $1 \cdot 6$ \\
\hline EP-S 938 & Field isolate & J. Frey & $1 \cdot 6$ \\
\hline EP-S 939 & Field isolate & J. Frey & $1 \cdot 6$ \\
\hline VPP11 & Field isolate & R. Ross & $1 \cdot 6$ \\
\hline 232 & Field isolate & R. Ross & $1 \cdot 6$ \\
\hline 1361 & Field isolate & R. Ross & $1 \cdot 6$ \\
\hline 1424 & Field isolate & R. Ross & $1 \cdot 6$ \\
\hline $\mathrm{J}$ & ATCC 25934 & R. Ross & $1 \cdot 8$ \\
\hline $\mathrm{J}$ & ATCC 25934 & P. Ahrens & $1 \cdot 8$ \\
\hline 15 unnamed strains & Field isolates & P. Ahrens & $1 \cdot 6$ \\
\hline
\end{tabular}

* ATCC, American Type Culture Collection, Rockville, MD, USA; NCTC, National Collection of Type Cultures, London, UK.

various laboratories. The sources of these strains are presented in Table 1.

Plasmid pMR7 containing the complete 23S rDNA of $M$. byopneumoniae (strain J ATCC 27719) was kindly provided by R. Hermann (ZMBH, Heidelberg University, Germany) (Taschke et al., 1986)

Primers. Primers HP1 and HP3 were designed from the nucleotide sequence of I-141 and synthesized on an Applied Biosystems DNA synthesizer. The HP1 primer sequence was 5'TTCAAATTATAACCTCGGTC- $3^{\prime}$ and the HP3 primer sequence was 5'-AGCAAATTTAGTCTCTCTGC-3'.

PCR amplification. Amplification was performed in a final volume of $50 \mu \mathrm{l}$ in a DNA thermal cycler (Perkin-Elmer Cetus). Each reaction mixture contained: 2.5 units Taq polymerase; $1 \mu \mathrm{M}$ of each of the primers HP1 and HP3; $200 \mu \mathrm{M}$ of each of the deoxynucleoside triphosphates (dNTPs); assay buffer (Tris/HCl, $70 \mathrm{mM}, \mathrm{pH} 8) ; \mathrm{MgCl}_{2}, 2 \mathrm{mM}$; $\left(\mathrm{NH}_{4}\right)_{2} \mathrm{SO}_{4}, 17 \mathrm{mM}$; $\beta$-mercaptoethanol, $10 \mathrm{mM}$; BSA, $200 \mu \mathrm{g} \mathrm{ml}^{-1}$ and dimethyl sulphoxide (DMSO), $5 \%(\mathrm{v} / \mathrm{v})$. Reaction mixtures were overlaid with mineral oil, heated at $92{ }^{\circ} \mathrm{C}$ for $10 \mathrm{~min}$ and submitted to 40 PCR cycles. Each cycle consisted of $1 \mathrm{~min}$ at $92{ }^{\circ} \mathrm{C}, 1 \mathrm{~min}$ at $57^{\circ} \mathrm{C}$ and $2 \mathrm{~min}$ at $72^{\circ} \mathrm{C}$. After 40 cycles an extension step for $10 \mathrm{~min}$ at $72^{\circ} \mathrm{C}$ was performed.

DNA cloning and sequencing. The amplified DNA fragments of $1.8 \mathrm{kbp}$ obtained from strain J (NCTC 10110) and used for cloning were phenol-extracted, after removal of oligonucleotides by spin dialysis on a Centricon-30 concentrator (Amicon) as recommended by the manufacturer. The fragments were phosphorylated and ligated into the HincII site of either pUC18 or M13 vector as described by Sambrook et al. (1989). The resulting plasmids were used to transform $E$. coli TG1 cells by the method of Hanahan (1983).
The preparation of single-stranded DNA templates and performance of annealing reactions were as described in the Sequenase version 2.0 kit handbook (United States Biochemical).

Double-stranded plasmid DNA was prepared as described by Mierendorf \& Pfeffer (1987) and sequenced according to the procedure described in the Sequenase version 2.0 kit handbook using synthesized oligonucleotides as primers.

Initial comparisons between proteins of $M$. byopneumoniae and those in the GenBank/EMBL databases were performed using the program BLAST. Computer-assisted analysis of nucleotide and protein sequence data were performed with PC gene software. The Clustal and Genetics Computer Group (GCG) programs were used to calculate percentage identity (identical amino acids) and similarity (identical and equivalent amino acids) between aligned sequences.

DNA isolation and hybridization. Mycoplasma chromosomal DNA was isolated as described by Marmur (1961). Restriction enzyme digestions were performed according to the manufacturer's protocols (Life Technologie). DNA fragments were resolved on $0.8 \%$ agarose gels and transferred to nylon $\mathrm{N}+$ membranes (Amersham). Labelling and hybridization procedures using the I-141 probe were as previously described (Abiven et al., 1992).

\section{RESULTS}

\section{Sequencing of the I-141 DNA fragment}

The HindIII I-141 DNA fragment of $M$. byopneumoniae strain J-LP (obtained directly from ATCC, see Methods) was sequenced (GenBank accession number U02537) and 
(a)

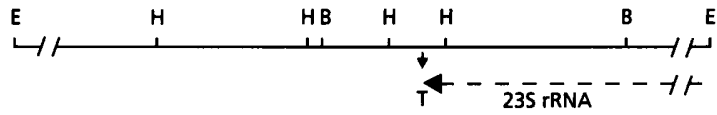

(b)

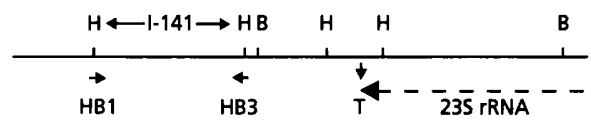

(c)

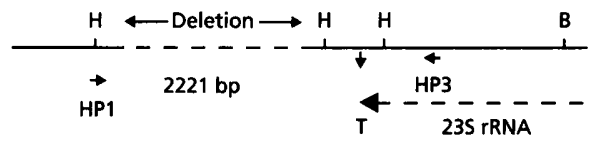

(d)

ORF1 $>$ ORF2 $>235$ rRNA

Fig. 1. Organization of $M$. hyopneumoniae DNA containing the HindIII I-141 fragment and ORFs 1 and 2. (a) Restriction map of the pMR7 plasmid insert containing the 23S rRNA gene as described by Taschke et al. (1986). (b) Organization of genomic DNA of J-LP (low passage) and field strains; the position of the HindIII I-141 DNA fragment is shown. (c) Genomic organization of other J strains; the 2221 bp deletion is shown as a dotted line. (d) Location and direction of transcription of the 235 rRNA gene and ORF1 and ORF2. E, EcoRl; H, HindIII; B, Bg/II; T, terminator of the $23 \mathrm{~S}$ rDNA gene (Taschke et al., 1986). The positions of primers HP1 and HP3 are indicated by arrows.

found to be $1618 \mathrm{bp}$ long. Its base composition was $37 \cdot 1 \% \mathrm{~A}, 36.9 \% \mathrm{~T}, 13.6 \% \mathrm{G}$ and $12.4 \% \mathrm{C}$. Taking UGA as a tryptophan codon (Yamao et al., 1985), two partial putative ORFs overlapping over eight nucleotides were identified. One ORF comprised nucleotides 1-592 and the other, nucleotides 585-1618.

To identify the two entire ORFs, the location of the I-141 DNA fragment on the $M$. byopneumoniae genome was determined and the adjacent DNA region sequenced.

\section{Localization of the I-141 fragment on $M$. hyopneumoniae genomic DNA}

The position of the I-141 DNA fragment on the $M$. byopneumoniae genome was mapped by field inversion gel electrophoresis (FIGE) and Southern blot hybridizations (data not shown). I-141 was found in the vicinity of $\mathrm{rrl}$ and rrs encoding, respectively, the $23 \mathrm{~S}$ rRNA and $16 \mathrm{~S}$ rRNA genes, and more precisely the region near the terminator of the $23 \mathrm{~S}$ rRNA gene ( $\mathrm{J}$. Frey, unpublished data).

Taschke et al. (1986) showed that $r r s$ and $r r l$ were singlecopy genes with a short intergenic region. The $23 \mathrm{~S}$ rRNA gene, including the terminator, was located on a $7 \mathrm{kbp}$ EcoRI DNA fragment which was subsequently cloned (Taschke et al., 1986) in a plasmid named pMR7 (Fig. 1a). In the present study, the use of the HindIII I-141DNA fragment as a probe in Southern blot hybridizations with restricted genomic DNA of $M$. byopneumoniae J-LP showed that I-141 hybridized to the $7 \mathrm{kbp}$ EcoRI DNA fragment

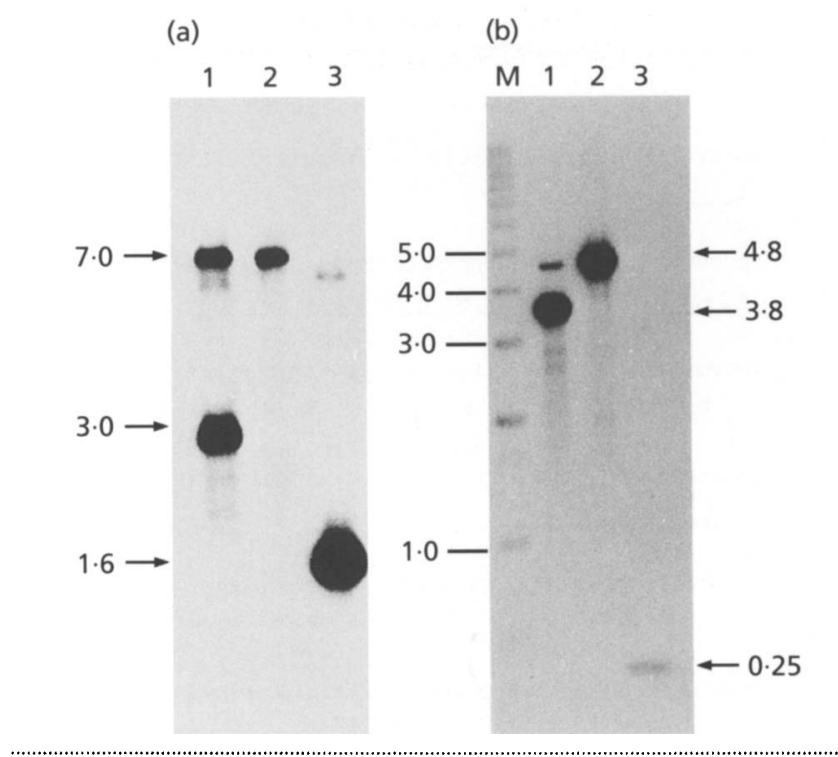

Fig. 2. Southern blot analysis of genomic DNA of $M$. hyopneumoniae J-LP strain (a) and a representative $J$ strain (b) with the radiolabelled 1-141 probe. DNA was restricted by EcoRI/BgIII (lane 1), EcoRI (lane 2) or HindlII (lane 3). Lane M contains molecular mass standards (1 kpb DNA ladder, BRL). Sizes are indicated in $\mathrm{kbp}$.

(Fig. 2a, lane 2) and to a $1.6 \mathrm{kbp}$ HindIII (lane 3) and a $3 \mathrm{kbp}$ EcoRI $/ B g / \mathrm{II}$ (lane 1) fragment. Hybridizations between HindIII I-141 DNA as probe and the pMR7 insert digested by the same enzymes gave the same result (data not shown). Thus, the results indicate that the HindIII I-141 DNA fragment hybridizes with the HindIII fragment of the pMR7 DNA insert described by Taschke et al. (1986).

\section{Nucleotide sequence analysis of the PMR7 insert}

To obtain the full sequence of the two ORFs on I-141, we sequenced the pMR7 insert from the terminator of the 23S rRNA gene to the I-141 fragment with internal primers; we also sequenced the 630 nucleotides upstream of the HindIII site of the I-141 fragment (Fig. 1 line a). The entire sequence (GenBank accession number U19889) comprised 3788 bp (Fig. 3).

No coding sequence was found on the strand harbouring the $23 \mathrm{~S}$ rRNA gene. However, the complementary strand showed two overlapping ORFs (Fig. 3). The first one, designated ORF1, extended from nucleotides 62 to 1661 and the other, from nucleotides 1656 to 3266 . The two ORFs each had an ATG initiation codon and a TAA stop codon.

The $3^{\prime} \mathrm{OH}$ end of the $16 \mathrm{~S}$ rRNA of $M$. byopneumoniae had the sequence ACCUCCUUUCUA-3'OH (Stemke et al., 1992). Preceding the ATG codon of ORF1 (nucleotide 62) was a Shine-Dalgarno ribosome-binding sequence (AGGAGGT) complementary to the sequence of the 
1

RBS

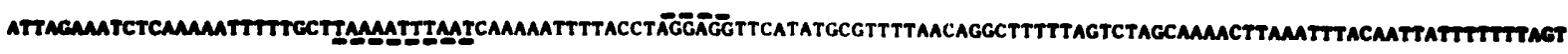
$-10$

ORF1-M R F N R L F S L A K L K I I I I I L V

121

MATCTTAATAMAGACGCGCGATTTCTAACCCATATTSTTACCTACAAGTTTATTTTTGAGTATTTTTCAGAGAAAAACCCTACTTTTAACCTAMCTTGGTCCCTAATTTTOTTCCTMAT

LI I E G P L T H I F S Y K F I F E Y F S E K N P T F N L T W S L L L L L 241

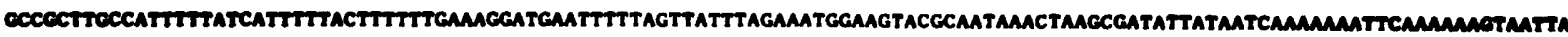

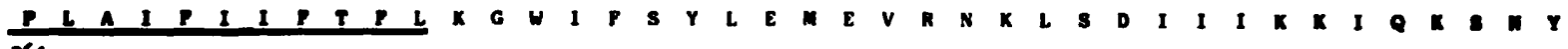
361

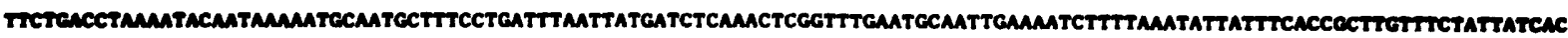

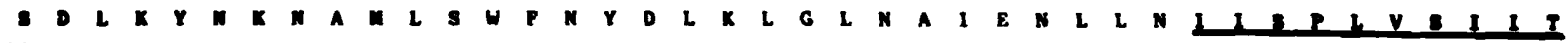
41

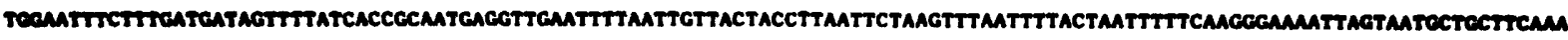

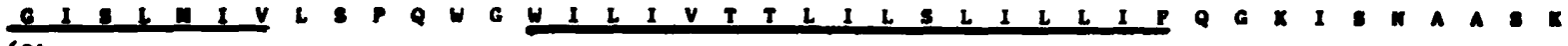
601

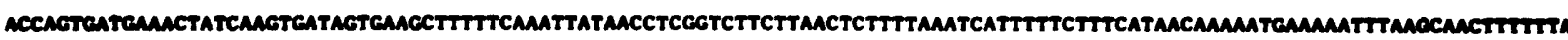

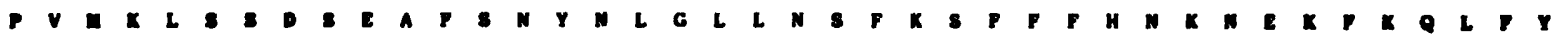
721

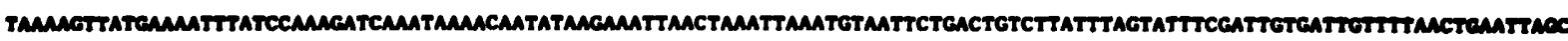

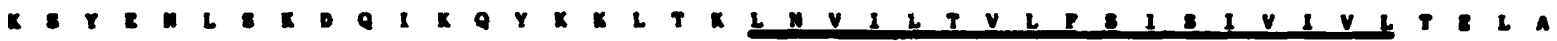
an1

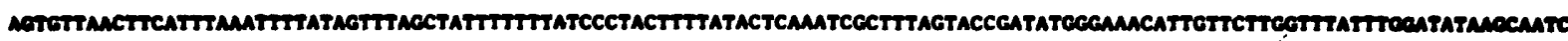

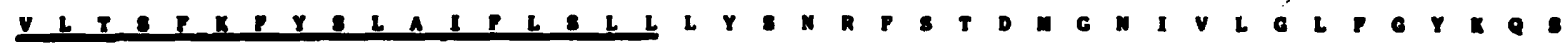
961

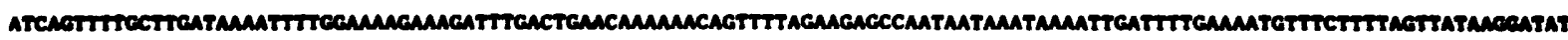

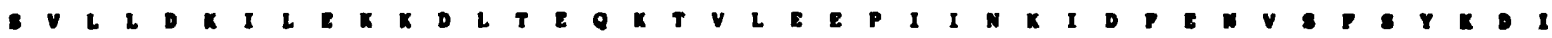
2081

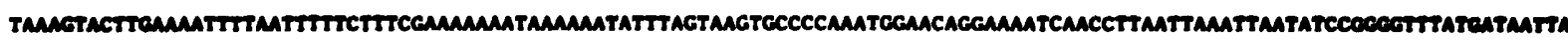

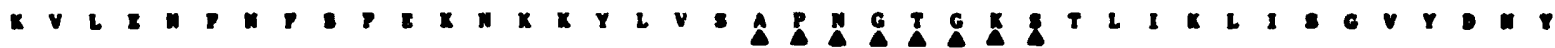
1201

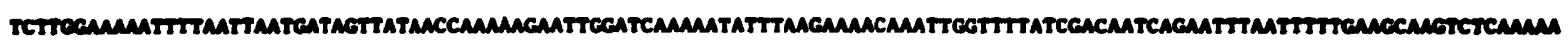

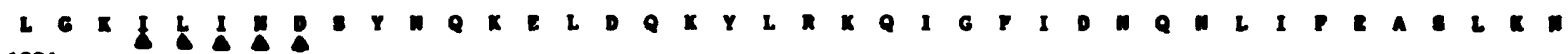
1321

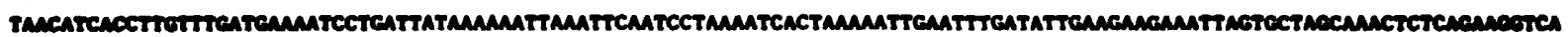

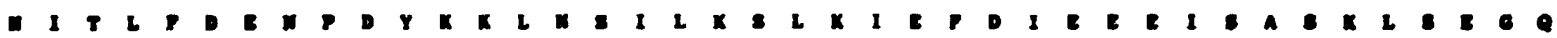
141

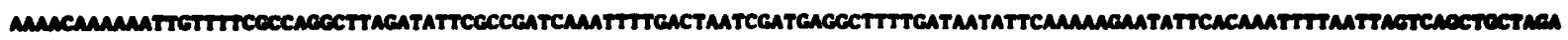

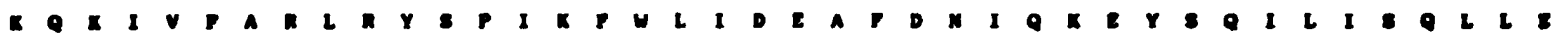
156110

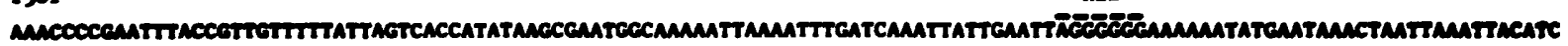

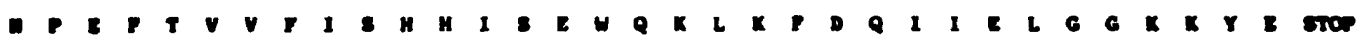

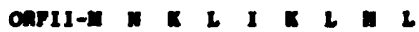

161

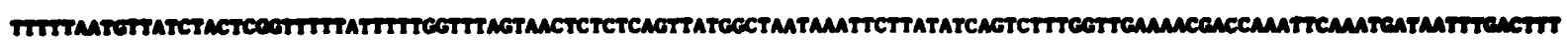

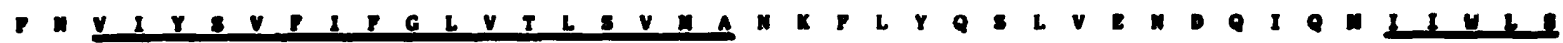
1801

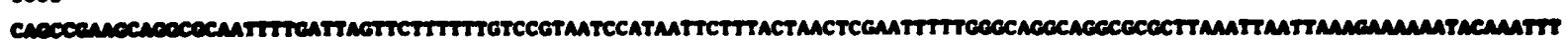

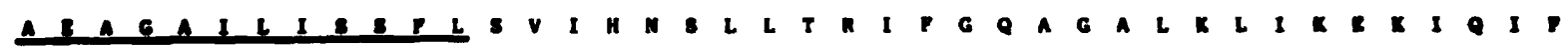
1921

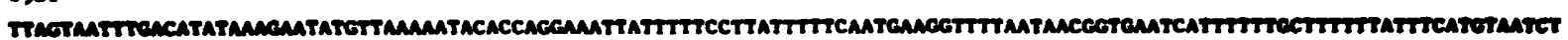

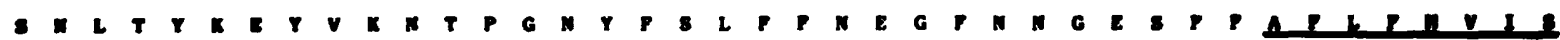
2001

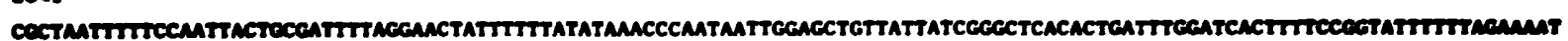

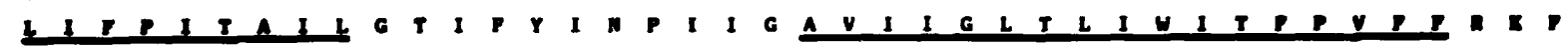
2161

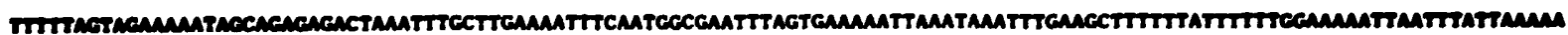

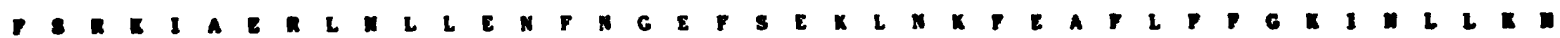

Fig. 3. For legend see facing page. 
2281

ATTTTтTAACCCCMACACCAMMAAAGCAAGTATTGGCCAMAAATCTTACAGATTTTGAAATGAATTTAATGCTAATATTAATTTAAGCATCCGTAAACTTTTCCTEATTTTAMCAGATC

P L P TA K X A B I G Q K B Y R P W N E P N A N I N L B I N X L P L I L T D L

2401

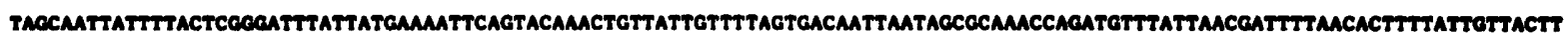

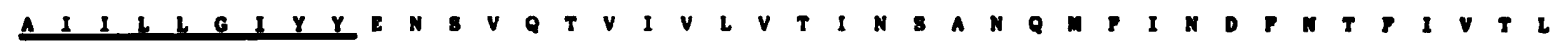
2521

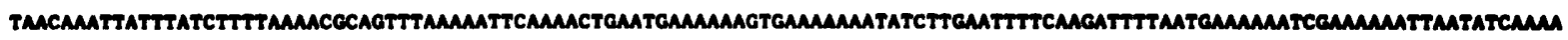

T Y L : P T Q P X N S X L N E X B E X N I L N P Q D F N E X I E K I N I K N 2641

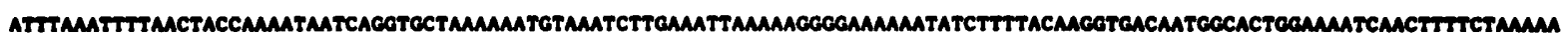

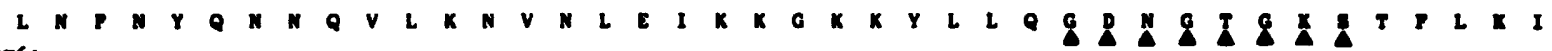
2761

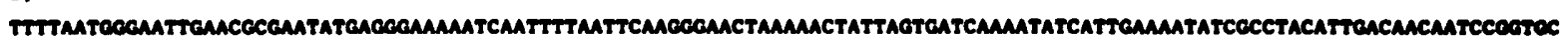

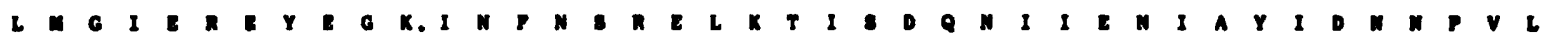
2881

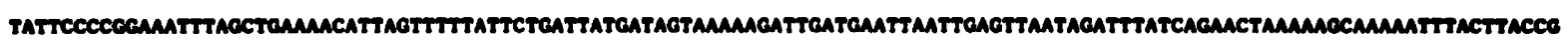

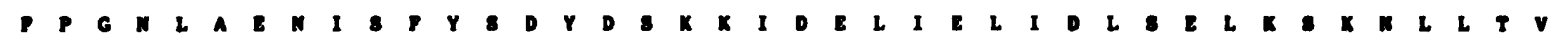
3001

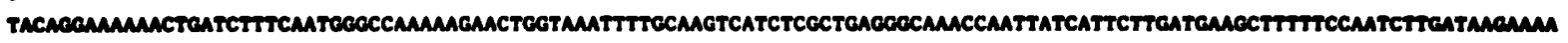

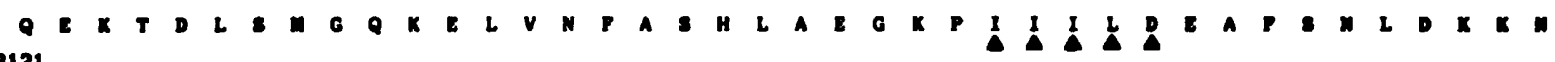
3121

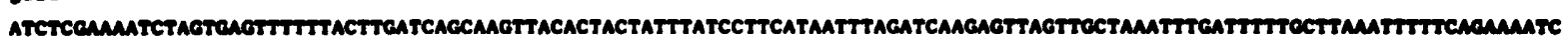

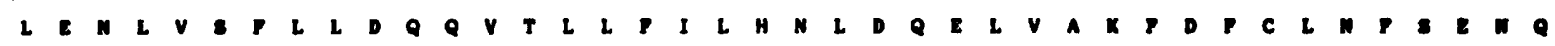
3241

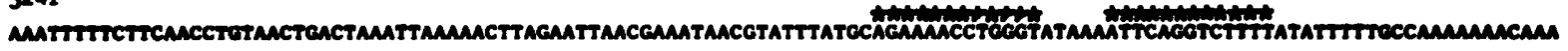

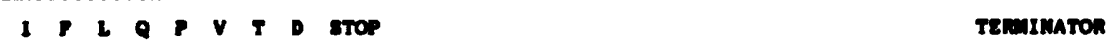

3361

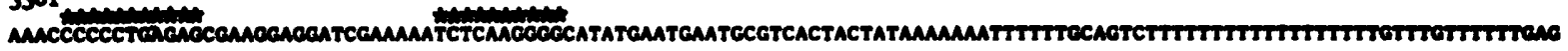
233 TEmolmaton

$34 \mathbf{4 1}$

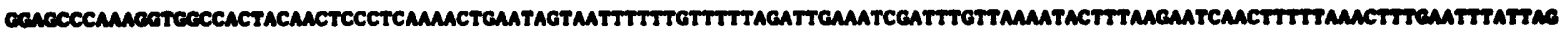
$\longleftarrow 238$ direction

3601

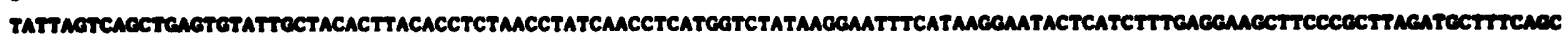
3721

COTtATCtTtTCCGTACtTACCTACCCACCTATCCCTtTGGCAMGACCACTGGAACACCAGCGGTACG

Fig. 3. Nucleotide sequence of 3788 bp of pMR7 located downstream of the 235 rRNA gene and predicted amino acids of the two ORFs. Potential - 10 sequence promoters and ribosome-binding sites (RBS) are shown. Transcription terminators are indicated by stars. Underlined amino acid sequences represent putative membrane-spanning domains. Amino acid sequences marked by triangles represent binding motifs characteristic of ATP/GTP-binding sites.

above $3^{\prime} \mathrm{OH}$ end of the $16 \mathrm{~S}$ rRNA. Similarly, the sequence AGGGGG, which precedes the ATG codon at nucleotide 1656 (ORF2), could pair with five bases at the $3^{\prime}$ end of the 16S rRNA. Upstream of ORF1, two consensus sequences for -10 boxes of transcription promoters were located at nucleotides 26-31 and 31-36 (Fig. 3). They differed by only one nucleotide from the consensus sequence (TATAAT) characteristic of promoters recognized by eubacterial RNA polymerase functioning with the general $\sigma$ factor. No classic consensus sequence for a -35 region was found.

An inverted repeat beginning at nucleotide 3308 may represent a Rho-independent terminator (Fig. 3). The terminator of the $23 \mathrm{~S}$ rRNA gene, determined by Taschke \& Hermann (1986) and located between two HindIII sites, was found between nucleotides 3364 and 3403 on the complementary strand (Fig. 3).
Analysis of the amino acid sequence encoded by ORF1 and ORF2

The putative protein product encoded by ORF1 (1661 bp) comprised 532 amino acid residues (PR1) and that by ORF2 (1613 bp) 536 residues (PR2). The predicted amino acid sequences of the two proteins were $26 \%$ identical and $55 \%$ similar. Database comparisons of the deduced amino acid sequences of PR1 and PR2 revealed significant similarities with proteins belonging to the $A B C$ transporter family, and particularly with the eukaryotic multi drug resistance (MDR) proteins.

The amino acid sequence of PR 1 protein showed $21 \%$ identity and $47 \%$ similarity with amino acid residues 701-1280 of mouse MDR3 protein (accession number P21447), and the PR2 peptide showed $23 \%$ identity and $50 \%$ similarity to amino acids $1-635$ of MDR3. Amino acid residues $340-393$ of the PR1 protein showed $30 \%$ 


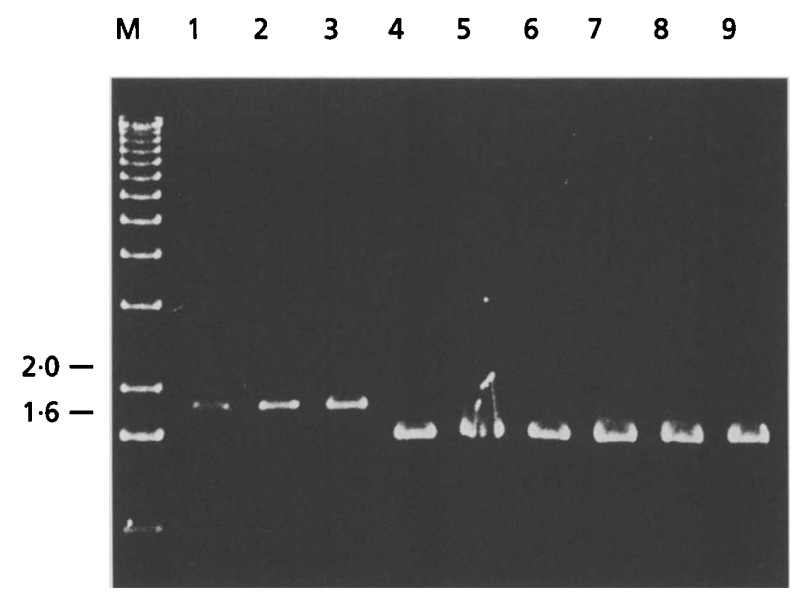

Fig. 4. Analysis of the PCR products obtained using HP1 or HP3 primers with different $M$. hyopneumoniae strains. Lanes: 1-9, amplified DNA fragments from strains J (ATCC 25934), J (NCTC 10110), JF 184, EP 29, BQ 14, EP-S 924, EP-S 938, EP-S 939 and J-LP (ATCC 25934), respectively; $M$, molecular mass standards (1 kbp DNA ladder). Sizes are indicated on the left in kbp.

identity and $60 \%$ similarity with two regions of the MDR sequence comprising residues 400-486 and 1040-1200. Similarly, residues $339-431$ of PR2 were $26 \%$ identical and $56 \%$ similar to the MDR sequences between amino acid residues 399-450 and 1093-1133. Two putative nucleotide-binding motifs characteristic of ATP/GTPbinding sites are present in the PR1 and PR2 proteins (shown by black triangles in Fig. 3), at amino acid positions 358-365 and 382-386, and 357-364 and 475-479 respectively (Fath \& Kolter, 1993).

Comparison of PR1 and PR2 hydropathy plots with those of MDR proteins also revealed some similarities. The MDR proteins are characterized by several membranespanning $\alpha$-helices present within hydrophobic domains (Gros et al., 1986). Six and five putative membranespanning domains were found in the $\mathrm{N}$-terminal halves of proteins PR1 and PR2, respectively (Fig. 3, amino acids underlined). All comprised 17 consecutive hydrophobic or uncharged residues. No signal peptide was found at the $\mathrm{N}$-terminal end of the protein. The amino acid sequences at the C-terminal region of PR1 and PR2 were strongly conserved and correspond to ATP-binding sites.

\section{Search for PR1 and PR2 proteins in various $M$. hyopneumoniae strains}

PCR analysis was used to investigate whether all $M$. byopneumoniae strains contain DNA coding for the PR1 and PR2 proteins. Two primers, HP1 and HP3, were selected using the I-141 DNA sequence to amplify a $1.6 \mathrm{kbp}$ DNA fragment. PCR products from the DNA of different $M$. byopneumoniae strains were then analysed on agarose gels (Fig. 4). According to the strain used an amplified DNA fragment of 1.6 or $1.8 \mathrm{kbp}$ was obtained (Table 1).
With all field strains tested and one strain (ATCC 25934) obtained directly from ATCC and passaged less than 10 times in our laboratory (J-LP), a $1.6 \mathrm{kbp}$ amplified DNA fragment of the same size as the I-141 DNA fragment was obtained (Fig. 4, lanes 4-9). However, DNA of strain J obtained from some other laboratories gave a $1.8 \mathrm{kbp}$ amplified DNA fragment (Fig. 4, lanes 1 to 3).

Southern hybridization conducted with the restricted DNA from J strain ATCC 25934 provided by J. Frey (Fig. $2 \mathrm{~b}$ ) revealed that the I-141 probe hybridized with a $0.25 \mathrm{kbp}$ HindIII DNA fragment instead of the $1.6 \mathrm{kbp}$ fragment expected (lane 3). The I-141 probe also hybridized with a $4.8 \mathrm{kbp}$ EcoRI DNA fragment (lane 2) and a $3.8 \mathrm{kbp} E c o \mathrm{RI} / B g / \mathrm{II}$ DNA fragment (lane 1). The $4.8 \mathrm{kbp}$ EcoRI DNA fragment was replaced by a $7 \mathrm{kbp}$ fragment in the J-LP strain (Fig. 2a) and in the field strains.

In view of the different sizes of the amplified DNA fragments, we cloned and sequenced the $1.8 \mathrm{kbp}$ amplified DNA fragment.

\section{Nucleotide sequence analysis of the $1.8 \mathrm{kbp}$ amplified DNA fragment}

Sequencing of the $1.8 \mathrm{kbp}$ amplified DNA fragment (GenBank accession number U02538) revealed that the DNA region comprising nucleotides 1620 to 1824 was $100 \%$ homologous to the $3^{\prime}$ end of fragment I-141 (nucleotides 1407-1611). The other 1620 nucleotides were $100 \%$ homologous to the $3^{\prime}$ end of the 23S rRNA gene, including the terminator of the gene located between two HindIII sites. Surprisingly, sequence analysis also revealed that primer HP3 hybridized with a DNA fragment present on the $23 \mathrm{~S}$ rRNA gene with only $55 \%$ homology. This sequence (5'-AGT'TT'TTGTGTCGAGAGACG-3') is located 1280 nucleotides from the $23 \mathrm{~S}$ terminator determined by Taschke \& Hermann (1986). Nucleotide sequence alignment of the $1.8 \mathrm{kbp}$ amplified DNA fragment, the I-141 DNA fragment and pMR7 of Taschke et al. (1986) containing $r \mathrm{rl}$, indicates that $2221 \mathrm{bp}$ have been deleted from the DNA of $M$. byopneumoniae J strains provided by other laboratories (Fig. 1c). These $M$. byopneumoniae strains lack genes coding for the putative $\mathrm{ABC}$ transporter proteins.

\section{DISCUSSION}

Intraspecies genomic polymorphism among field and reference strains of $M$. byopneumoniae has been described previously (Frey et al., 1992). Our studies have revealed genomic heterogeneity among $M$. byopneumoniae field and culture collection strains. Differences have also been noted between strain J (ATCC 25934) received from ATCC and cultured for only a few passages in Friis medium in our laboratory (strain J-LP) and the same strain cultured elsewhere. Our results showed that some of the latter strains have lost a DNA fragment of $2221 \mathrm{bp}$ in a region close to the terminator of the $23 \mathrm{~S} r R N A$ gene. For M. byopneumoniae J-LP, the DNA fragment upstream of the terminator of $23 \mathrm{~S}$ rRNA had no ORF on the DNA strand coding for the 23S rRNA gene, but two over- 
lapping ORFs on the complementary strand. These two ORFs were part of a single transcription unit.

The amino acid sequences of the two proteins, PR1 and PR2, encoded by the two ORFs, showed significant homology with eukaryotic and prokaryotic $A B C$ transporters (Fath \& Kolter, 1993). All ABC transporters have an ATP-binding domain and membrane-spanning domains (MSDs). Generally, bacterial $A B C$ importers have the ATP-binding domain and MSDs on separate polypeptides, whereas bacterial $\mathrm{ABC}$ exporters can have these two components on the same or on different polypeptides. In the case of eukaryotic ABC transporters, the ATPbinding domain and MSDs are located on the same protein (Fath \& Kolter, 1993).

The highest homology was found between PR1 or PR2 and the mouse multidrug resistance protein MDR3. Homology was also evident with the secretion protein HlyB of the RTX haemolysin of E. coli (Holland et al., 1990 ) and the SpaB protein of Bacillus subtilis (Klein et al., 1992). The homology between eukaryotic multidrug resistance proteins (P-glycoprotein or MDR) and bacterial transport proteins has been described previously (Gros $e t$ al., 1986). The P-glycoprotein of eukaryotic cells is a large polypeptide consisting of four domains equivalent to the two hydrophobic and the two ATP-binding components of a bacterial periplasmic transport system (Higgins $e t$ al., 1990). Gros et al. (1986) reported that the homology between MDR proteins and the bacterial transport proteins occurred within the internal duplication of the MDR in the region of greatest conserved homology (residues $400-600$ and $1000-1250$ of MDR). These sequences include the highly conserved ATP-binding cassette which is the most characteristic feature of the $\mathrm{ABC}$ transporter superfamily. Each half of a MDR protein is similar to a single bacterial transport protein, suggesting that the gene has evolved from a common ancestor by gene duplication or gene fusion events (Lincke et al., 1991; Croop, 1993).

In PR1 or PR2, the ATP-binding domain and MSDs are present on the same polypeptide. Thus, PR1 together with PR2 could act as the entire MDR protein or as two bacterial transporters.

Homology between proteins of $\mathrm{ABC}$ transporter systems and mollicute proteins has been described previously, in particular for Mycoplasma byorbinis, a frequently isolated pathogenic mycoplasma (Dudler et al., 1988; Gilson et al., 1988). Three proteins encoded by a single operon, showed similarities with proteins of periplasmic binding-proteindependent transport systems of Gram-negative bacteria. In our case, PR1 and PR2 also showed homology with the E. coli haemolysin export protein, HlyB.

These results were unexpected because mycoplasmas are known to be more related to Gram-positive bacteria than to Gram-negative bacteria (Weisburg et al., 1989). Secretion by mycoplasmas involves passage through only one membrane, the plasma membrane, and resembles more closely the process in Gram-positive bacteria and eukaryotic cells than in Gram-negative bacteria where two membranes are involved. When high levels of homology are observed over large evolutionary distances, strong functional relationships can usually be identified.

$A B C$ transporter proteins are involved in import or export functions of a large variety of substrates including sugars, peptides, proteins and toxins (Higgins, 1992). The MDR proteins are often involved in the export of drugs and detoxification processes. The HlyB protein of E. coli (together with HlyD) is involved in the export of a haemolysin protein. Haemolysin activity has been examined in a variety of mycoplasmas but in comparison to species such as Mycoplasma pulmonis and Acboleplasma laidlawii, activity in $M$. byopneumoniae was insignificant (Minion \& Jarvill-Taylor, 1994).

The fact that some culture collection strains do not possess the gene coding for PR1 and PR2 is interesting. These strains were not grown in our laboratory, but such strains are routinely cultivated and often subcloned. Thus, the number of passages, or selection of clones by subtyping could explain such difference amongst strains. Strain J maintained in vitro for 60 passages was unable to cause pneumonia in pigs (Zielinsky \& Ross, 1990). Moreover, the capacity of $M$. byopneumoniae to induce epithelial damage in porcine tracheal organ culture diminished with in vitro passage (Debey \& Ross, 1994). Attenuation of virulence through successive in vitro passage has similarly been described for $M$. pulmonis (Taylor-Robinson et al., 1981) and $M$. pneumoniae (Collier et al., 1985). Such loss of virulence arising from a lack of selective pressure (Ott, 1993) may lead to the identification of the genes involved in pathogenicity. Further experiments are needed to determine the role of PR1 and PR2 and whether their absence is correlated with lack of virulence.

\section{ACKNOWLEDGEMENTS}

Thanks are due to A. Labbe for technical assistance in $M$. byopneumoniae culture and P. Duthil for photographs. We thank Dr Hermann and Dr Rosengarten and all laboratories which sent us plasmids or DNA from different $M$. byopneumoniae strains. We particularly thank Dr Joachim Frey for critical reading and critical discussion of the manuscript.

\section{REFERENCES}

Abiven, P., Blanchard, B., Saillard, C., Kobisch, M. \& Bové, J. M. (1992). A specific DNA probe for detecting Mycoplasma byopneumoniae in experimentally infected piglets. Mol Cell Probes 6, 423-429.

Blanchard, B., Vena, M. M., Cavalier, A., Le Lannic, J., Gouranton, J. \& Kobisch, M. (1992). Electron microscopic observation of the respiratory tract of SPF piglets inoculated with Mycoplasma byopneumoniae. Vet Microbiol 30, 329-341.

Bolske, G., Strandberg, M. L., Bergström, K. \& Johansson, K. E. (1987). Species-specific antigens of Mycoplasma byopneumoniae and cross-reactions with other porcine mycoplasmas. Curr Microbiol 15, 233-239.

Bové, J. M. (1993). Molecular features of Mollicutes. Clinical Inf Dis 17, 10-31.

Collier, A. M., Hu, P. C. \& Clyde, W. A. (1985). The changing pathogenicity of Mycoplasma pneumoniae with passage 'in vitro' correlates of virulence. Diagn Microbiol Infect Dis 3, 321-326. 
Croop, J. M. (1993). P-glycoprotein structure and evolutionary homologies. Cytotechnology 12, 1-323.

Debey, M. C. \& Ross, R. F. (1994). Ciliostatis and loss of cilia induced by Mycoplasma byopneumoniae in porcine tracheal organ culture. Infect Immun 62, 5312-5318.

Dudler, R., Schmidhauser, C., Parish, R. W., Wettenhall, R. E. \& Schmidt, T. (1988). A mycoplasma high-affinity transport system and the in vitro invasiveness of mouse sarcoma cells. EMBO $J 7$, 3963-3970.

Fath, M. \& Kolter, R. (1993). ABC transporters : bacterial exporters. Microbiol Rev 57, 995-1017.

Frey, J., Haldimann, A. \& Nicolet, J. (1992). Chromosomal heterogeneity of various Mycoplasma byopneumoniae field strains. Int J Syst Bacteriol 42, 275-280.

Gilson, G., Alloing, G., Schmidt, T., Claverys, J. P., Dudler, R. \& Hofnung, M. (1988). Evidence for high affinity binding-protein dependent transport systems in Gram-positive bacteria and in Mycoplasma. EMBO J 7, 3971-3974.

Gros, P., Croop, J. \& Housman, D. (1986). Mammalian multidrug resistance gene: complete $\mathrm{cDNA}$ sequence indicates strong homology to bacterial transport proteins. Cell 47, 371-380.

Hanahan, D. (1983). Studies on transformation of Escherichia coli with plasmids. $J$ Mol Biol 166, 557-580.

Higgins, C. F. (1992). ABC transporters: from microorganisms to man. Annu Rev Cell Biol 8, 67-113.

Higgins, C. F., Clyde, S. C., Mimmack, M. M., Gileadi, U., Gill, D. R. \& Gallagher, M. P. (1990). Binding protein-dependent transport systems. J Bioenerg Biomembr 22, 571-592.

Holland, I. B., Kenny, B. \& Blight, M. (1990). Haemolysin secretion from E. coli. Biocbimie 72, 131-141.

Hovind-Hougen, K. \& Friis, N. F. (1991). Morphological and ultrastructural studies of Mycoplasma flocculare and Mycoplasma byopneumoniae in vitro. Res Vet Sci 51, 155-163.

Klein, C., Kaletta, C., Schnell, N. \& Entian, K. D. (1992). Analysis of genes involved in biosynthesis of the lantibiotic subtilin. Appl Environ Microbiol 58, 132-142.

Kobisch, M., Labbé, A., Morvan, P., Le Moine, M. M., Beaurepaire, B., Cariolet, R. \& Pansart, J. F. (1993). Un modèle expérimental associant $M$. byopneumoniae et $A$. pleuropneumoniae. Journée de la Recherche Porcine en France 25, 339-344.

L'Ecuyer, C. \& Boulanger, P. (1970). Enzootic pneumonia of pigs: identification of a causative mycoplasma in infected pigs and in cultures by immuno-fluorescent staining. Can J Comp Med 34, $38-46$.

Lincke, C. R., Smit, J., Velde-Koerts, T. \& Borst, P. (1991). Structure of the human MDR 3 gene and physical mapping of the human MDR locus. $J$ Biol Cbem 266, 5303-5310.
Marmur, J. (1961). A procedure for the isolation of deoxyribonucleic acid from micro-organisms. J Mol Biol 3, 208-218.

Mierendorf, R. C. \& Pfeffer, D. (1987). Direct sequencing of denatured plasmid DNA. Methods Enzymol 152, 556-562.

Minion, C. F. \& Jarvill-Taylor, K. (1994). Membrane-associated hemolysin activities in mycoplasma. FEMS Microbiol Lett 116, 101-106.

Ott, M. (1993). Dynamics of the bacterial genome: deletions and integrations as mechanisms of bacterial virulence modulation. Zentralbl Bakteriol 278, 457-468.

Ross, R. F. (1992). Mycoplasmal diseases. In Diseases of Swine, 7th edn, pp. 537-551. Edited by A. D. Leman, B. Straw, W. L. Mengeling, S. D'Allaire \& D. J. Taylor. Ames: Iowa State University Press.

Sambrook, J., Fritsch, E. F. \& Maniatis, T. (1989). Molecular Cloning: a Laboratory Manual, 2nd edn. Cold Spring Harbor, NY: Cold Spring Harbor Laboratory.

Stemke, G. W., Laigret, F., Grau, O. \& Bové, J. M. (1992). Phylogenetic relationships of three porcine mycoplasmas, Mycoplasma byopneumoniae, Mycoplasma flocculare, and Mycoplasma byorbinis, and complete $16 \mathrm{~S}$ rRNA sequence of $M$. flocculare. Int J Syst Bacteriol 42, 220-225.

Taschke, C. \& Herrmann, R. (1986). Analysis of transcription and processing signals of the 16S-23S rRNA operon of Mycoplasma byopneumoniae. Mol Gen Genet 205, 434-441.

Taschke, C., Klinkert, M. Q., Wolters, J. \& Herrmann, R. (1986). Organization of the ribosomal RNA genes in Mycoplasma byopneumoniae: the 5S rRNA gene is separated from the $16 \mathrm{~S}$ and $23 \mathrm{~S}$ rRNA genes. Mol Gen Genet 205, 428-433.

Taylor-Robinson, D., Furr, P. M. \& Davies, H. A. (1981). Mycoplasmal adherence with particular reference to the pathogenicity of Mycoplasma pulmonis. Isr J Med Sci 17, 599-603.

Weisburg, W. G., Tully, J. G., Rose, D. L., Petzel, J. P., Oyaizu, H., Yang, D., Mandelco, L., Sechrest, J., Lawrence, T. G., Van Etten, J., Maniloff, J. \& Woese, C. R. (1989). A phylogenetic analysis of the mycoplasmas: basis for their classification. $J$ Bacteriol 171, 6455-6467.

Yamao, F., Muto, A., Kawauchi, Y., Iwami, M., Iwagami, S., Azumi, Y. \& Osawa, S. (1985). UGA is read as tryptophan in Mycoplasma capricolum. Proc Natl Acad Sci US A 82, 2306-2309.

Zielinsky, G. \& Ross, R. F. (1990). Effect of growth in cell cultures and strain on virulence of Mycoplasma byopneumoniae for swine. Am $J$ Vet Res 51, 344-348.

Received 25 September 1995; revised 29 February 1996; accepted 5 March 1996. 